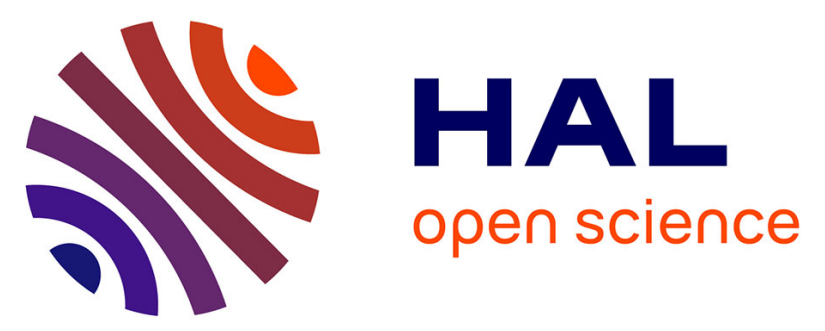

\title{
OH-substituted tridentate ONO Schiff base ligands and related molybdenum(VI) complexes for solvent-free (ep)oxidation catalysis with TBHP as oxidant
}

\author{
Weili Wang, Jean-Claude Daran, Rinaldo Poli, Dominique Agustin
}

\section{To cite this version:}

Weili Wang, Jean-Claude Daran, Rinaldo Poli, Dominique Agustin. OH-substituted tridentate ONO Schiff base ligands and related molybdenum(VI) complexes for solvent-free (ep)oxidation catalysis with TBHP as oxidant. Journal of Molecular Catalysis A: Chemical, 2016, 416, pp.117-126. 10.1016/j.molcata.2016.02.021 . hal-01929759

\section{HAL Id: hal-01929759 \\ https://hal.science/hal-01929759}

Submitted on 1 Mar 2021

HAL is a multi-disciplinary open access archive for the deposit and dissemination of scientific research documents, whether they are published or not. The documents may come from teaching and research institutions in France or abroad, or from public or private research centers.
L'archive ouverte pluridisciplinaire HAL, est destinée au dépôt et à la diffusion de documents scientifiques de niveau recherche, publiés ou non, émanant des établissements d'enseignement et de recherche français ou étrangers, des laboratoires publics ou privés. 
OH-Substituted Tridentate ONO Schiff base ligands and related molybdenum(VI) complexes for solvent-free (ep)oxidation catalysis with TBHP as oxidant.

Weili Wang, ${ }^{\text {a,b }}$ Jean-Claude Daran, ${ }^{\text {a } R i n a l d o ~ P o l i, ~}{ }^{\text {acc }}$ Dominique Agustin*a,b

${ }^{a}$ CNRS; LCC (Laboratoire de Chimie de Coordination); Université de Toulouse; UPS, INPT, 205, route de Narbonne, F-31077 Toulouse, France Fax: $+33-561553003$

${ }^{b}$ Université de Toulouse; Institut Universitaire de Technologie Paul Sabatier - Département de Chimie, Av. Georges Pompidou, BP 20258, F-81104 Castres Cedex, France E-mail: dominique.agustin@iut-tlse3.fr.

${ }^{c}$ Institut Universitaire de France 103, bd Saint-Michel, 75005 Paris, France

\begin{abstract}
Molybdenum complexes with ONO tridentate Schiff base ligands based on salicylideneaminophenolato (SAP) backbone with $\mathrm{OH}$ substitution on the salicyl arene ring have been synthesized and characterized. The molecular structures of the full series of $\mathrm{OH}$ substituted molybdenum complexes were determined by X-ray crystallography as monomers stabilized by one solvent molecule, $\left[\mathrm{MoO}_{2} \mathrm{~L}(\mathrm{D})\right]$. All dimeric complexes $\left[\mathrm{MoO}_{2} \mathrm{~L}\right]_{2}$ were tested for the epoxidation of cyclooctene and cyclohexene under organic solvent-free conditions using aqueous TBHP as oxidant. The position of the $\mathrm{OH}$ on the SAP-modified ligand influenced the catalytic activity of the respective complexes. DFT calculations for the catalytic cycle yield energy spans in agreement with the experimentally observed activity trend.
\end{abstract}

\title{
Keywords
}

Molybdenum, solvent-free, epoxidation, DFT, X-ray structures 


\section{Introduction}

Epoxides are useful reagents for different applications in fine chemistry and polymer chemistry [1]. They are generally obtained through classical organic reactions using organic oxidants (metachloroperbenzoic acid or $m$-CPBA, $\mathrm{CH}_{3} \mathrm{CO}_{3} \mathrm{H}$ or $\mathrm{PhIO}$ ), with the use of organic solvents (often chlorinated) or ionic liquids [2]. The organic by-products produced by these oxidants and the solvents can be considered as waste, increasing the E factor [3,4]. In addition, certain chlorinated solvents are potentially toxic and their use in several industrial sectors is not recommended [5]. Therefore, using a lower amount of solvent or a safer one or, even better, no organic solvent at all represents a challenging benefit for green chemistry. Catalysis brings several advantages to green chemistry in general, and in the particular case of epoxidation processes also through the possibility to replace the above mentioned oxidants with others having lower environmental impact (e.g. tertbutylhydroperoxide or TBHP, $\mathrm{H}_{2} \mathrm{O}_{2}, \mathrm{O}_{2}$ ). There are, however, economic and safety issues about the amount (cost) of the needed catalyst and its toxicity. Molybdenum is the most commonly used transition metal in academic and industrial applications of epoxidation catalysis [6], in combination with many different supporting ligands. We and others have been interested in the use of tridentate ONO and ONS Schiff base ligands in combination with molybdenum in organic solvents [7] and without solvent $[8,9]$. We have recently shown high catalytic efficiencies at relatively low metal loadings for different types of molybdenum and vanadium complexes $[8,10]$ as well as for polyoxometalates [11] for the epoxidation of cyclooctene as a model substrate and of bio-sourced compounds [12] using aqueous TBHP as oxidant and no added organic solvent. Several advantages can be pointed out for these processes. The by-product and waste product ( $t \mathrm{BuOH}$ and water) are nontoxic and can be recycled, $t \mathrm{BuOH}$ being also used as additive in the gasoline industry as well as for the synthesis of methyl tert-butyl ether (MTBE) [13]. The salicylideneaminophenolato (SAP) and salicylideneaminothiophenolato (SATP) ligands have yielded good results in terms of reaction efficiency and catalyst stability [8] under these organic solvent-free conditions. Using DFT calculations, we have also established that the intimate mechanism of the catalytic cycle involves activation of TBHP by coordination to the catalytic metal without proton transfer followed by oxygen transfer to the olefin in a way that closely resembles the mechanism proposed by Bartlett for the stoichiometric epoxidation with peracids [14]. Slight improvements of these results could be achieved by tuning the SAP ligand through the addition of electron donor $\left(\mathrm{NEt}_{2}\right)$ and/or acceptors $\left(\mathrm{NO}_{2}\right)$ substituents on the ligand backbone [15]. Therefore, we have wondered whether the introduction of simple $\mathrm{OH}$ groups on the SAP ligand backbone could also positively affect the catalyst performance. The synthesis and characterization of the modified systems as well as the catalytic test on different substrates will be discussed herein. 


\section{Results and discussion}

\subsection{Synthesis and characterization}

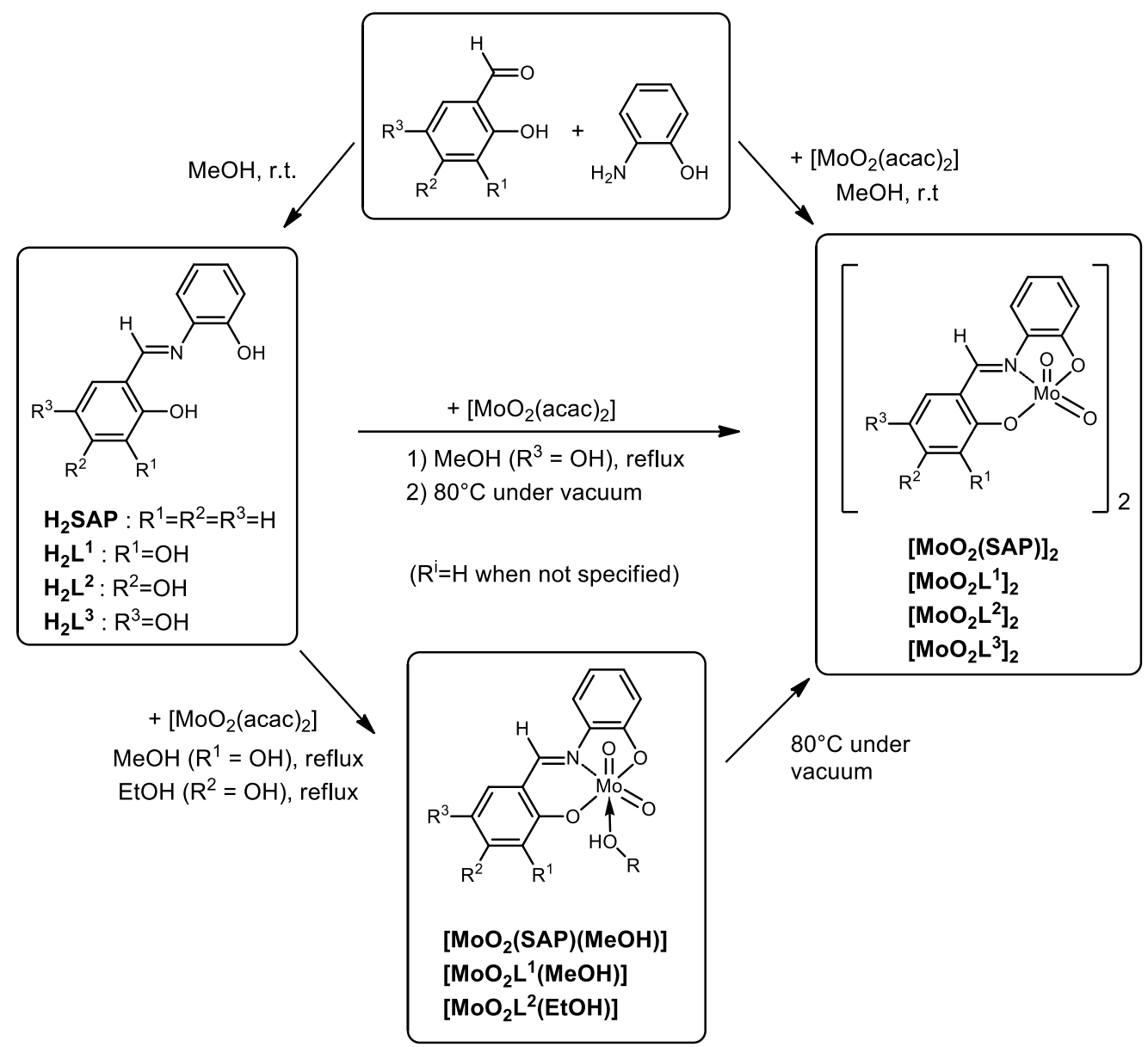

Scheme 1. Access routes to the $\mathrm{H}_{2} \mathrm{~L}$ pro-ligands and molybdenum complexes.

\subsubsection{Synthesis}

Reaction of the previously reported $[16,17,18,19] \mathrm{H}_{2} \mathrm{~L}^{1-3}$ molecules with $\left[\mathrm{MoO}_{2}(\mathrm{acac})_{2}\right]$ in refluxing alcohol gave, by analogy with the parent $\mathrm{H}_{2} \mathrm{SAP}$ ligand $[8 \mathrm{a}, 20]$ and with other related systems [20], either mononuclear alcohol adducts, $\left[\mathrm{MoO}_{2} \mathrm{~L}(\mathrm{ROH})\right]$, or oligonuclear $\left[\mathrm{MoO}_{2} \mathrm{~L}\right]_{\mathrm{n}}$ depending on the nature of the ligands and on the reaction conditions (see Scheme 1). The reaction of $\mathrm{H}_{2} \mathrm{~L}^{1}$ in $\mathrm{EtOH}$ and $\mathrm{H}_{2} \mathrm{~L}^{2}$ in $\mathrm{MeOH}$ yielded the new mononuclear complexes $\left[\mathrm{MoO}_{2} \mathrm{~L}^{1}(\mathrm{EtOH})\right]$ and $\left[\mathrm{MoO}_{2} \mathrm{~L}^{2}(\mathrm{MeOH})\right]$, respectively, which could be transformed to the alcohol free systems upon drying under vacuum at high temperatures. The recovered product of the reaction of $\mathrm{H}_{2} \mathrm{~L}^{3}$ and $\left[\mathrm{MoO}_{2}(\mathrm{acac})_{2}\right]$ was dried directly to yield $\left[\mathrm{MoO}_{2} \mathrm{~L}^{3}\right]_{\mathrm{n}}$.

\subsubsection{IR Characterizations}

The most relevant IR spectroscopic properties of the new complexes are collected in Table 1 and compared with those of the previously reported ligands and $\left[\mathrm{MoO}_{2}(\mathrm{SAP})\right]_{2}$ complex. The key 
feature in the IR spectrum of the $\mathrm{H}_{2} \mathrm{SAP}$ and $\mathrm{H}_{2} \mathrm{~L}^{1-3}$ molecules is the $\mathrm{C}=\mathrm{N}$ stretching vibration around $1600-1630 \mathrm{~cm}^{-1}$. Bonding of $\mathrm{L}^{2-}$ to the $\left\{\mathrm{MoO}_{2}{ }^{2+}\right\}$ fragment is accompanied by a small red shift of this band to the $1600-1610 \mathrm{~cm}^{-1}$ region. The vibration pattern of the $\left\{\mathrm{MoO}_{2}{ }^{2+}\right\}$ fragment observed between 750 and $1100 \mathrm{~cm}^{-1}$ gives additional information about the form of the isolated complex, particularly those associated to the terminal $\mathrm{Mo}=\mathrm{O}$ bonds that appear in the $850-950 \mathrm{~cm}^{-1}$ region. For the solvent stabilized monomeric species of general formula $\left[\mathrm{MoO}_{2} \mathrm{~L}(\mathrm{D})\right]$, two sharp bands are observed around 910 and $940 \mathrm{~cm}^{-1}$, whereas the dimeric or oligomeric $\left[\mathrm{MoO}_{2} \mathrm{~L}\right]_{\mathrm{n}}$ feature only one $\mathrm{Mo}=\mathrm{O}$ vibration in this region, plus another band corresponding to a Mo-O-Mo vibration at lower frequency (760-820 $\left.\mathrm{cm}^{-1}\right)[21]$.

Table 1. Selected IR vibrations $\left(v, \mathrm{~cm}^{-1}\right)$ of the $\mathrm{H}_{2} \mathrm{SAP}, \mathrm{H}_{2} \mathrm{~L}^{1-3}$, $\left[\mathrm{MoO}_{2} \mathrm{~L}^{\mathrm{n}}(\mathrm{ROH})\right](\mathrm{n}=1,2)$, $\left[\mathrm{MoO}_{2}(\mathrm{SAP})\right]_{2}$ and $\left[\mathrm{MoO}_{2} \mathrm{~L}^{1-3}\right]_{2}$ compounds.

\begin{tabular}{|l|l|l|l|l|}
\cline { 2 - 5 } \multicolumn{2}{c|}{} & $\mathrm{C}=\mathrm{N}$ & $\mathrm{Mo}=\mathrm{O}$ & Mo-O-Mo \\
\hline Pro-ligands & $\mathrm{H}_{2} \mathrm{SAP}$ & 1633 & - & - \\
& $\mathrm{H}_{2} \mathrm{~L}^{1}[17]$ & 1618 & - & - \\
& $\mathrm{H}_{2} \mathrm{~L}^{2}[18]$ & 1603 & - & - \\
& $\mathrm{H}_{2} \mathrm{~L}^{3}[19]$ & 1612 & - & - \\
\hline Complexes & {$\left[\mathrm{MoO}_{2}(\mathrm{SAP})\right]_{2}[8 \mathrm{a}]$} & 1608 & 937 & 790 \\
& {$\left[\mathrm{MoO}_{2} \mathrm{~L}^{1}(\mathrm{MeOH})\right]$} & 1612 & 908,933 & \\
& {$\left[\mathrm{MoO}_{2} \mathrm{~L}^{1}\right]_{2}$} & 1612 & 919 & 780 \\
& {$\left[\mathrm{MoO}_{2} \mathrm{~L}^{2}(\mathrm{EtOH})\right]$} & 1600 & 908,945 & \\
& {$\left[\mathrm{MoO}_{2} \mathrm{~L}^{2}\right]_{2}$} & 1598 & 904 & 821 \\
& {$\left[\mathrm{MoO}_{2} \mathrm{~L}^{3}\right]_{2}$} & 1613 & 912 & 804 \\
\hline
\end{tabular}

\subsubsection{NMR Characterizations}

The ${ }^{1} \mathrm{H}$ NMR spectrum of the $\mathrm{H}_{2} \mathrm{~L}^{1-3}$ molecules in DMSO- $\mathrm{d}^{6}$ shows distinct resonances for the three $\mathrm{OH}$ groups of the substituted salicylidene ring (see SI), indicating their slow mutual exchange. Complexation to molybdenum leads to the disappearance of two of the three $\mathrm{OH}$ resonances in each case and to a weak shift of the imine resonance. Note that, since all NMR measurements of the dioxomolybdenum complexes were carried out in DMSO- $\mathrm{d}^{6}$, the observed spectrum of each product, whether mononuclear alcohol adduct or alcohol-free oligomer, corresponds to the $\left[\mathrm{MoO}_{2} \mathrm{~L}(\mathrm{DMSO})\right]$ adduct. 


\subsubsection{TG analyses}

The thermogravimetric analyses of the isolated $\left[\mathrm{MoO}_{2} \mathrm{~L}^{1-2}(\mathrm{ROH})\right]$ complexes show loss of the alcohol molecule below $200^{\circ} \mathrm{C}$, followed by loss of the Schiff base ligand at higher temperatures (up to $600^{\circ} \mathrm{C}$ ). The second process is also observed for the alcohol free oligomers, leaving $\mathrm{MoO}_{3}$ as a residue as previously observed with similar ligands [22]. The relevant data are collected in Table 2 , in comparison with the parent $\left[\mathrm{MoO}_{2}(\mathrm{SAP})\right]_{2}$ compound.[8a]

Table 2. Mass losses of the molybdenum complexes by TG analyses.

\begin{tabular}{|l|l|l|l|l|}
\hline \multirow{2}{*}{ Complex } & \multicolumn{2}{|l|}{$\Delta \mathrm{m}_{1}\left(<250^{\circ} \mathrm{C}\right)$} & \multicolumn{2}{l|}{$\Delta \mathrm{m}_{2}$} \\
\cline { 2 - 5 } & Exp & Theo & Exp & Theo \\
\hline$\left[\mathrm{MoO}_{2}(\mathrm{SAP})\right]_{2}[8 \mathrm{a}]$ & - & - & 58.5 & 57.6 \\
{$\left[\mathrm{MoO}_{2} \mathrm{~L}^{1}(\mathrm{MeOH})\right]$} & 8.3 & 9.8 & 62.8 & 63.4 \\
{$\left[\mathrm{MoO}_{2} \mathrm{~L}^{1}\right]_{2}$} & - & - & 59.1 & 59.5 \\
{$\left[\mathrm{MoO}_{2} \mathrm{~L}^{2}(\mathrm{EtOH})\right]$} & 11.6 & 11.5 & 65.0 & 64.1 \\
{$\left[\mathrm{MoO}_{2} \mathrm{~L}^{2}\right]_{2}$} & - & - & 59.2 & 59.5 \\
{$\left[\mathrm{MoO}_{2} \mathrm{~L}^{3}\right]_{2}$} & - & - & 58.7 & 59.5 \\
\hline
\end{tabular}

\subsection{X-ray structures}

All $\mathrm{L}^{n}$ systems $(n=1,2,3)$ have given crystals suitable for a structural determination by $\mathrm{X}$-ray diffraction in the form of solvent-stabilized mononuclear complexes. For $n=1$ and 3, crystals were obtained from DMSO as $\left[\mathrm{MoO}_{2} \mathrm{~L}^{n}(\mathrm{DMSO})\right]$, whereas for ligand $\mathrm{L}^{2}$ the crystal was obtained from an acetonitrile/water mixture as the water adduct, $\left[\mathrm{MoO}_{2} \mathrm{~L}^{2}\left(\mathrm{H}_{2} \mathrm{O}\right)\right]$. The complex $\left[\mathrm{MoO}_{2} \mathrm{~L}^{2}(\mathrm{DMSO})\right]$ was also crystallized but its structure could not be satisfactorily refined because of a severe disorder problem. The common feature of all these complexes is a pseudo-octahedral geometry around the molybdenum center and a cis arrangement for the $\left\{\mathrm{MoO}_{2}\right\}^{2+}$ fragment, which is surrounded by an ONO tridentate ligand in a mer arrangement and by a sixth donor molecule D (D being DMSO or $\mathrm{H}_{2} \mathrm{O}$ ), in accordance with the structures of similar compounds [15, 20h, 22, 23]. Views of the molecules are shown in Figure 1.
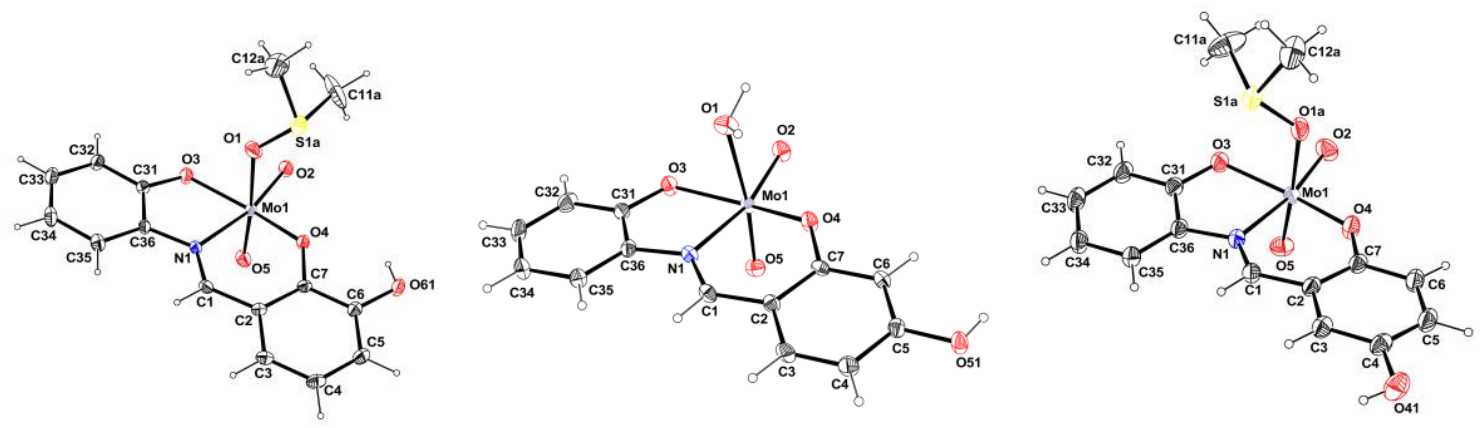

Figure 1. Molecular view of compound $\left[\mathrm{MoO}_{2} \mathrm{~L}^{1}(\mathrm{DMSO})\right]$ (left), $\left[\mathrm{MoO}_{2} \mathrm{~L}^{2}\left(\mathrm{H}_{2} \mathrm{O}\right)\right]$ (center) and $\left[\mathrm{MoO}_{2} \mathrm{~L}^{3}(\mathrm{DMSO})\right]$ (right) with the atom labelling scheme. Displacement ellipsoids are drawn at the 
$50 \%$ probability level. For the sake of clarity, only one component of the disordered DMSO is represented.

The $\left[\mathrm{MoO}_{2} \mathrm{~L}^{1}(\mathrm{DMSO})\right]$ complex crystallizes as an $\mathrm{H}$-bonded dimer, the interaction being established between the free $\mathrm{OH}$ group of the ligand (O61 atom) of one molecule as a proton donor with one of the oxido ligands ( $\mathrm{O} 2$ atom) of the second one as a proton acceptor, see Figure 2 and relevant bonding parameters in the supporting information (Table S1).

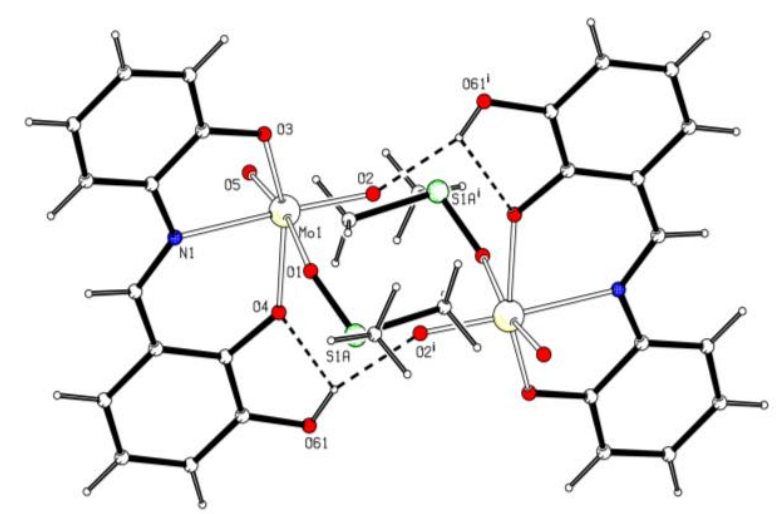

Figure 2. View of the dinuclear unit formed by intermolecular hydrogen bonds between two $\left[\mathrm{MoO}_{2} \mathrm{~L}^{1}(\mathrm{DMSO})\right]$ molecules. Symmetry code: (i) $-\mathrm{x}+2,-\mathrm{y},-\mathrm{z}$.

On the other hand, the $\mathrm{L}^{3}$ complex does not show any intermolecular H-bonding but crystallizes with two additional DMSO molecules per complex in the crystal lattice, one of which is linked to the free $\mathrm{OH}$ group of the $\mathrm{L} 3$ ligand through an $\mathrm{O}-\mathrm{H} \cdots \mathrm{O}$ interaction (Figure 3 and Table $\mathrm{S} 2$ in the SI).

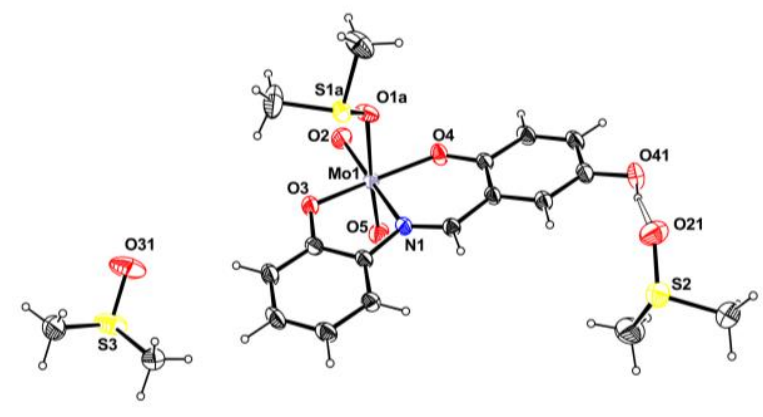

Figure 3. View of compound $\left[\mathrm{MoO}_{2} \mathrm{~L}^{3}(\mathrm{DMSO})\right] .2 \mathrm{DMSO}$ showing the hydrogen bond (dashed line) between the complex and one of the DMSO solvent molecule. Displacement ellipsoids are drawn at the $50 \%$ probability level. $\mathrm{H}$ atoms are represented as small spheres of arbitrary radii. The disordered part is omitted for clarity.

Finally, complex $\left[\mathrm{MoO}_{2} \mathrm{~L}^{2}\left(\mathrm{H}_{2} \mathrm{O}\right)\right]$ crystallizes with one molecule of acetonitrile, which is $\mathrm{H}$ bonded to the aqua ligand by a $\mathrm{O} 1-\mathrm{H} \cdots \mathrm{N} 2$ interaction. In addition, as for compound $\left[\mathrm{MoO}_{2} \mathrm{~L}^{1}(\mathrm{DMSO})\right]$, intermolecular H-bonding involving the free salicyl OH group (atom O51) of one 
molecule as a proton donor with one of the oxo groups (atom $\mathrm{O} 2$ ) of a second molecule as a proton acceptor is also established, yielding dimers in which the two ONO ligands are essentially coplanar. These dimers are further linked together in a 3-dimensional network via additional $\mathrm{H}$-bonds involving the water molecule $(\mathrm{O} 1)$ of one complex as a proton donor and the $\mathrm{OH}$ of a complex in another dimer (O51) as a proton acceptor (Figure 4 and Table S3 in SI).

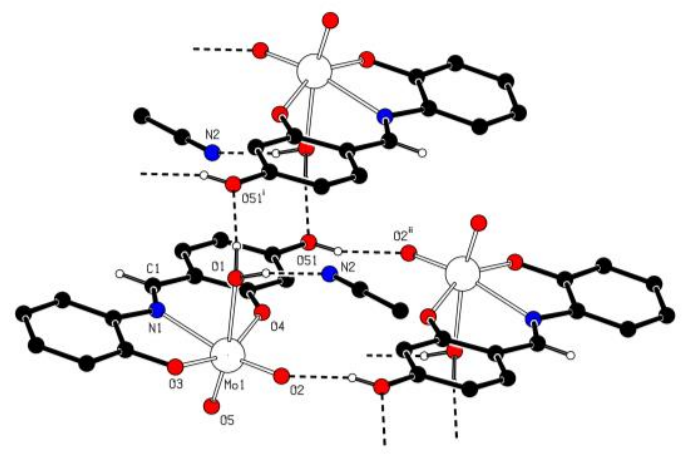

Figure 4. View of the intermolecular H-bonding network for compound $\left[\mathrm{MoO}_{2} \mathrm{~L}^{2}\left(\mathrm{H}_{2} \mathrm{O}\right)\right] \cdot \mathrm{CH}_{3} \mathrm{CN}$.

All relevant bond lengths and angles for the pseudo-octahedral $\left[\mathrm{MoO}_{2} \mathrm{~L}^{n}(\mathrm{D})\right]$ molecules are collected in Table 3. Interatomic distances around the molybdenum atom are very similar for all complexes. Some slight differences occur for the angles. The cis conformation of the $\mathrm{MoO}_{2}$ moiety is observed with $\mathrm{O}=\mathrm{Mo}=\mathrm{O}$ angles of $103.99^{\circ}$ and $103.88^{\circ}$ for $\mathrm{L}^{1}$ and $\mathrm{L}^{3}$ respectively, whereas a slightly wider angle of $105.2(1)^{\circ}$ is observed for the $\mathrm{L}^{2}$ complex (see) Table 3 and in accordance with similar structures [21e,g,h, 24]. The L ligands deviate slightly from coplanarity, with very similar dihedral angles for the $\mathrm{L}^{1}\left(10.6^{\circ}\right)$ and $\mathrm{L}^{3}\left(10.4^{\circ}\right)$ complexes, and even smaller for the $\mathrm{L}^{2}$ complex $\left(5.5^{\circ}\right)$.

Table 3. Relevant bond lengths around the molybdenum.

\begin{tabular}{|c|c|c|c|}
\hline & {$\left[\mathrm{MoO}_{2} \mathrm{~L}^{1}(\mathrm{DMSO})\right]$} & {$\left[\mathrm{MoO}_{2} \mathrm{~L}^{2}\left(\mathrm{H}_{2} \mathrm{O}\right)\right]$} & {$\left[\mathrm{MoO}_{2} \mathrm{~L}^{3}(\mathrm{DMSO})\right]$} \\
\hline \multicolumn{4}{|c|}{ Relevant Bonds (̊̊) } \\
\hline $\mathrm{Mo}=\mathrm{O}(2)$ & $1.714(2)$ & $1.731(3)$ & $1.7082(15)$ \\
\hline $\mathrm{Mo}=\mathrm{O}(5)$ & $1.698(2)$ & $1.696(3)$ & $1.7038(15)$ \\
\hline Mo-N & $2.277(2)$ & $2.252(3)$ & $2.2752(15)$ \\
\hline Мo-O(3) & $1.957(2)$ & $1.948(3)$ & $1.9673(13)$ \\
\hline Мo-O(4) & $1.943(2)$ & $1.944(3)$ & $1.9302(14)$ \\
\hline Mo-O(1) & $2.285(2)$ & $2.325(3)$ & $2.289(3)$ \\
\hline \multicolumn{4}{|c|}{ Relevant angles $\left({ }^{\circ}\right)$} \\
\hline $\mathrm{O}(2)-\mathrm{Mo}-\mathrm{O}(5)$ & $103.98(11)$ & $105.2(1)$ & $103.90(8)$ \\
\hline $\mathrm{O}(2)-\mathrm{Mo}-\mathrm{N}(1)$ & $164,32(10)$ & $163.0(1)$ & $164.78(7)$ \\
\hline $\mathrm{O}(3)-\mathrm{Mo}-\mathrm{O}(4)$ & $151,30(9)$ & $152.6(1)$ & $152.29(6)$ \\
\hline $\mathrm{O}(5)-\mathrm{Mo}-\mathrm{O}(1)$ & 169.11(10) & $169.5(1)$ & $172.14(10)$ \\
\hline
\end{tabular}




\subsection{Catalysis studies}

\subsubsection{Epoxidation of cyclooctene}

All synthesized complexes have been tested for the epoxidation of the model substrate cyclooctene by aqueous TBHP (Scheme 2) at $80^{\circ} \mathrm{C}$ without added organic solvent. Given the high concentration (70\% w/w) of the aqueous TBHP and the higher affinity of TBHP for cyclooctene, the reaction mixture consists of a majority of organic phase containing cyclooctene and TBHP and a small proportion of essentially neat water. The complexes are only slightly soluble in cyclooctene at room temperature but appear to dissolve completely in the organic phase after addition of TBHP at the reaction temperature. The organic phase is colored during the entire reaction procedure, whereas the water phase is colorless or very faintly colored. Standard catalytic tests were carried out using two equivalents of TBHP per cyclooctene and a $0.5 \% \mathrm{Mo} /$ substrate ratio.

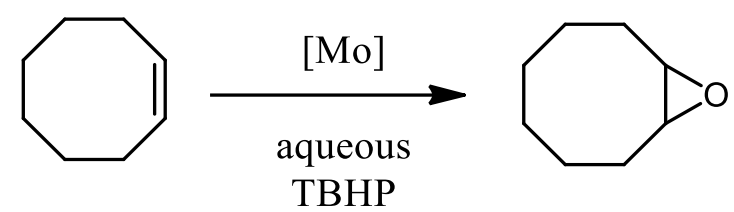

Scheme 2. Epoxidation of cyclooctene.

Introduction of a free $\mathrm{OH}$ group in the SAP system produced the effects illustrated in Figure 5. The selectivity and activity data are detailed in Table 4 . While the $\mathrm{OH}$ addition at the ortho $\left(\mathrm{L}^{1}\right)$ and para $\left(\mathrm{L}^{3}\right)$ positions of the salicyl ring (particularly the former) increased the catalytic activity relative to the reference SAP catalyst, substitution at the meta $\left(\mathrm{L}^{2}\right)$ position had essentially no effect. The selectivity towards cycloctene oxide is high (>85\%) with all catalysts. In the case of the $\mathrm{L}^{2}$ ligand, there is no significant difference between the ethanol-stabilized mononuclear and the oligomeric systems, suggesting that the two pre-catalysts may generate the same active species. This result is in agreement with our previous mechanistic work on the non-substituted SAP system, where it was concluded that the active catalyst is the 5-coordinate mononuclear $\left[\mathrm{MoO}_{2}(\mathrm{SAP})\right]$ species, with growing concentrations of added $\mathrm{MeOH}$ having only minor negative effect on the activity [8a]. The observed differences could be intuitively attributed to either a different catalyst solubility or at an electronic effect of the $\mathrm{OH}$ substituent. However, all complexes appeared totally soluble at the reaction temperature. The major acceleration when the free $\mathrm{OH}$ group lies in ortho position, followed by the $\mathrm{OH}$ substitution at the para position, seems to indicate a favorable electronic effect and suggests a transmission of this effect by a combination of the $\pi$ delocalization and inductive mechanisms. 


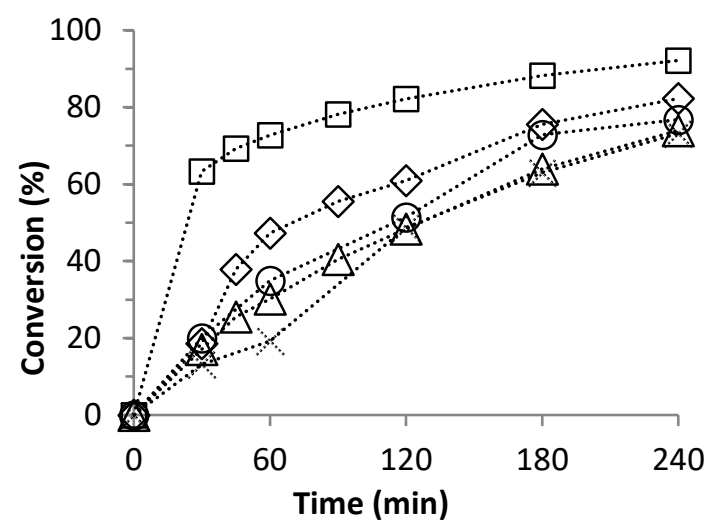

Figure 5. Cyclooctene conversion vs. time with different $\mathrm{ONO}$ based catalysts: $\left[\mathrm{MoO}_{2}(\mathrm{SAP})\right]_{2}(\mathrm{O})$, $\left[\mathrm{MoO}_{2} \mathrm{~L}^{1}\right]_{2}(\square),\left[\mathrm{MoO}_{2} \mathrm{~L}^{2}\right]_{2}(\times),\left[\mathrm{MoO}_{2} \mathrm{~L}^{2}(\mathrm{EtOH})\right](\Delta)$ and $\left[\mathrm{MoO}_{2} \mathrm{~L}^{3}\right]_{2}(\diamond)$. For the reaction conditions, see Table 4.

Table 4. Results of cyclooctene epoxidation by aqueous TBHP catalyzed by different molybdenum complexes. ${ }^{\mathrm{a}}$

\begin{tabular}{l|cclc}
\hline & $\begin{array}{c}\text { Conversion } \\
{[\%]}\end{array}$ & $\begin{array}{c}\text { Selectivity } \\
{[\%]}\end{array}$ & $\begin{array}{l}\mathrm{TOF}^{\mathrm{b}} \\
{\left[\mathrm{h}^{-1}\right]}\end{array}$ & TON \\
\hline$\left[\mathrm{MoO}_{2}(\mathrm{SAP})\right]_{2}$ & 76 & 93 & 70 & 153 \\
{$\left[\mathrm{MoO}_{2} \mathrm{~L}^{1}\right]_{2}$} & 92 & 93 & 251 & 184 \\
{$\left[\mathrm{MoO}_{2} \mathrm{~L}^{2}\right]_{2}$} & 73 & 85 & 71 & 146 \\
{$\left[\mathrm{MoO}_{2} \mathrm{~L}^{2}(\mathrm{EtOH})\right]$} & 74 & 90 & 68 & 148 \\
{$\left[\mathrm{MoO}_{2} \mathrm{~L}^{3}\right]_{2}$} & 81 & 91 & 127 & 163 \\
\hline${ }^{\mathrm{a}} \mathrm{Conditions}_{2} \mathrm{Mo} / \mathrm{TBHP} /$ cyclooctene $=0.5 / 100 / 200 ; \mathrm{T}=80^{\circ} \mathrm{C} ; \mathrm{t}$ \\
$=4 \mathrm{~h} .{ }^{\mathrm{b}} \mathrm{TOF}$ is calculated on the time interval with maximum \\
slope for the conversion plot.
\end{tabular}

The catalytic runs were also carried out with different catalyst loadings down to $0.1 \%$ for $\left[\mathrm{MoO}_{2}(\mathrm{SAP})\right]_{2}$ and $0.05 \%$ for $\left[\mathrm{MoO}_{2} \mathrm{~L}^{1}\right]_{2}$ (Figure 6). The selectivity remained approximately constant in the $92-95 \%$ range (see details in Table S5 in the SI) upon catalyst dilution for the experiments run with $\left[\mathrm{MoO}_{2} \mathrm{~L}_{1}\right]_{2}$, whereas it slightly deteriorated from $93 \%$ at $1 \%$ catalyst to $73 \%$ at $0.1 \%$ catalyst for the experiments run with $\left[\mathrm{MoO}_{2}(\mathrm{SAP})\right]_{2}$. The observed conversion after $4 \mathrm{~h}$ was approximately the same in the high catalyst concentration range and slightly decreased only when using very low loadings $(<0.2 \%)$, while the TOF correspondingly increased. This phenomenon is not expected for a stable and fully soluble catalyst, for which the rate is expected to be first order in catalyst and the TOF should not dependent on the catalyst concentration. The constant conversion in the higher catalyst concentration range suggests a saturation effect, which seems however contradicted by the visual evidence of full catalyst dissolution in the reaction medium. 

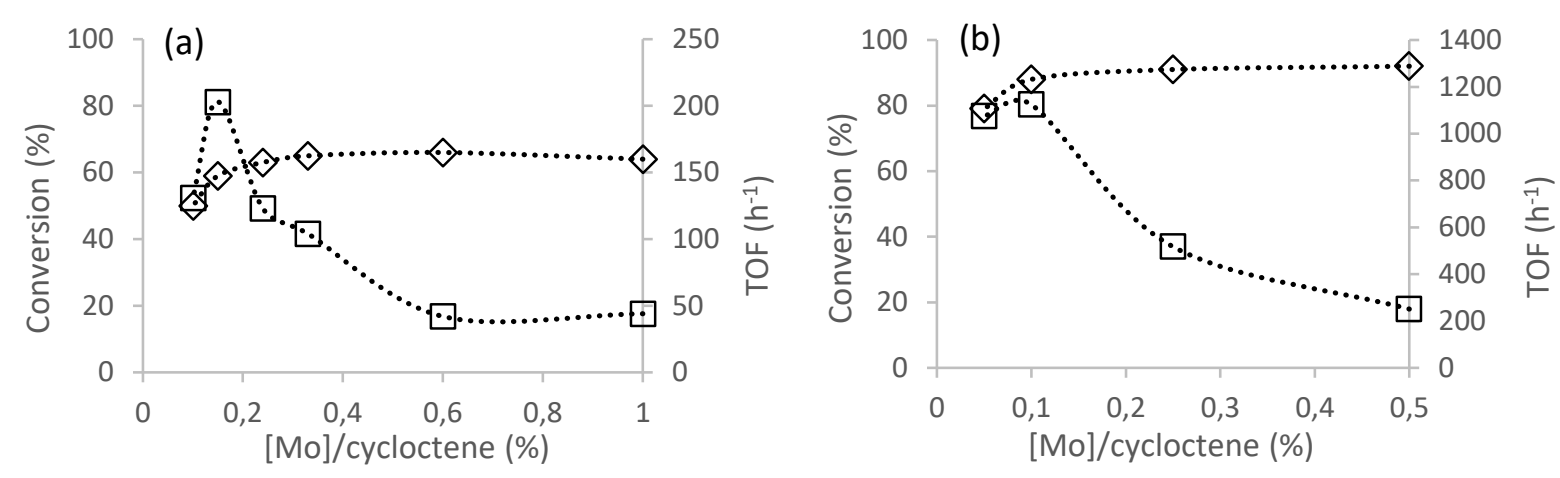

Figure 6. Conversion after $4 \mathrm{~h}(\diamond)$ and initial TOF $(\square)$ vs. [Mo]/cyclooctene ratio for the processes catalyzed by $\left[\mathrm{MoO}_{2}(\mathrm{SAP})\right]_{2}$ (a) and $\left[\mathrm{MoO}_{2} \mathrm{~L}^{1}\right]_{2}(\mathrm{~b})$.

Decreasing the amount of catalyst while keeping the substrate and TBHP amounts constant entails an increase of the water/[Mo] ratio. In order to probe the possible effect of water, additional experiments were carried out for catalysts $\left[\mathrm{MoO}_{2}(\mathrm{SAP})\right]_{2}$ and $\left[\mathrm{MoO}_{2} \mathrm{~L}^{1}\right]_{2}$ with constant amounts of catalyst, substrate and TBHP and (0.5/100/200) in the presence of increasing amounts of additional water. These catalytic runs yield only slightly lower TOF values at higher water/[Mo] ratios, showing a negative effect of water on the catalysis (for full details, see Table S6 in SI). Therefore, the dramatic TOF increase observed in Figure 6 at lower catalyst loading (greater water/[Mo] ratios) cannot be attributed to a chemical activation of the catalyst by water.

\subsubsection{Epoxidation of cyclohexene}

Cyclooctene oxide is quite robust compared to cyclohexene oxide relative to ring opening in the presence of water. Thus, cyclohexene oxidation by TBHP was also investigated with same catalysts. The catalytic procedure was carried out under the same conditions as for cyclooctene (at $80^{\circ} \mathrm{C}$ with 2 equivalent of aqueous TBHP) except for the use of a catalyst loading of only $0.1 \%$ mol vs. substrate, the catalysts being less soluble in this reaction mixture. The kinetic profiles for the substrate conversion are shown in Figure 7 and the main activity and selectivity results are collected in Table 5. Three main products detected within the organic phase for the oxidation of cyclohexene are cyclohexene oxide (CHO) from epoxidation, trans-1,2-cyclohexanediol (CHD) (due to $\mathrm{CHO}$ hydrolysis) and small traces of 2-cyclohexen-1-ol (CHol) from allylic oxidation, Scheme 3 [25].

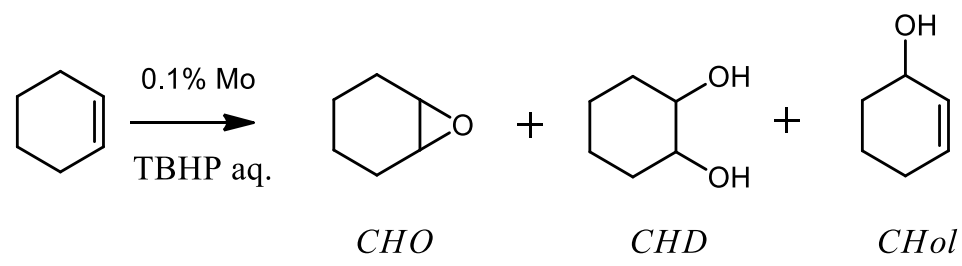

Scheme 3. Epoxidation of cyclohexene. 


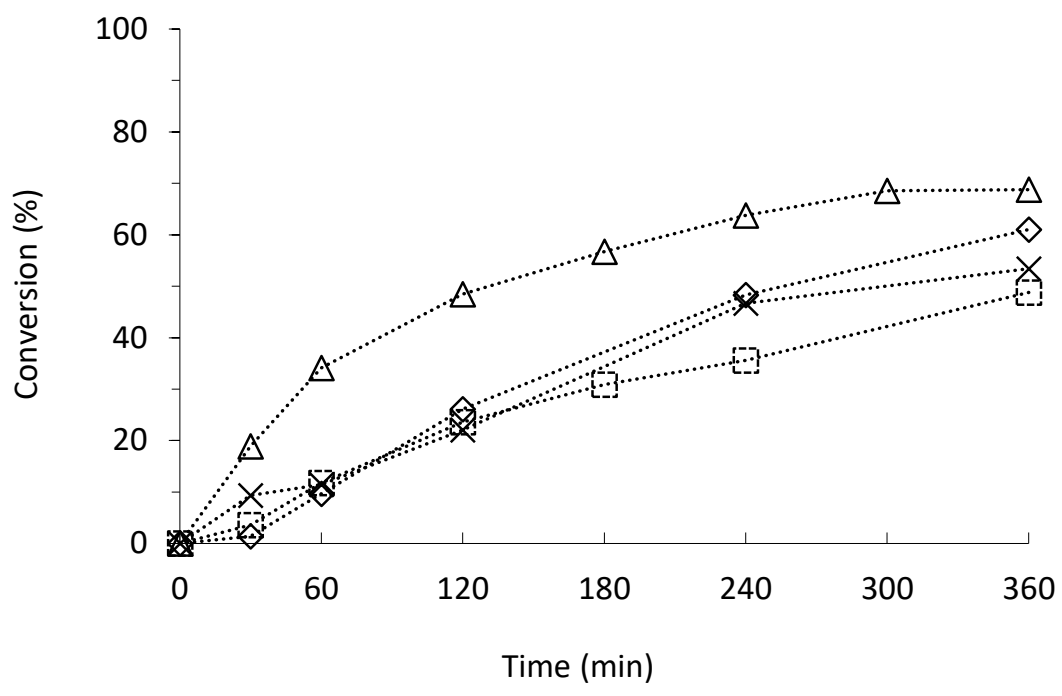

Figure 7. Kinetic profile of converted cyclohexene $v s$. time in the presence of dioxidomolybdenum(VI) catalysts: $\left[\mathrm{MoO}_{2}(\mathrm{SAP})\right]_{2}(\square),\left[\mathrm{MoO}_{2} \mathrm{~L}^{1}\right]_{2}(\triangle),\left[\mathrm{MoO}_{2} \mathrm{~L}^{2}\right]_{2}(\times),\left[\mathrm{MoO}_{2} \mathrm{~L}^{3}\right]_{2}(\diamond)$. Conditions: substrate/TBHP/[Mo] $=100: 200: 0.1 ; \mathrm{T}=80^{\circ} \mathrm{C}$.

Table 5. Results of cyclohexene oxidation by $\left[\mathrm{MoO}_{2}(\mathrm{SAP})\right]_{2}$ and $\left[\mathrm{MoO}_{2} \mathrm{~L}^{1-3}\right]_{2}$.

\begin{tabular}{l|c|c|c|c|c|c|c}
\hline \multirow{2}{*}{ catalyst } & \multirow{2}{*}{$\begin{array}{c}\text { Conversion } \\
(\%)\end{array}$} & \multirow{2}{*}{$\begin{array}{c}\text { Selectivity } \\
(\%) / \text { oxide }\end{array}$} & \multicolumn{3}{|c|}{ Yield (\%) } & TON & \multirow{2}{*}{$\begin{array}{c}\text { TOF } \\
\left(\mathrm{h}^{-1}\right)\end{array}$} \\
\hline$\left[\mathrm{MoO}_{2}(\mathrm{SAP})\right]_{2}$ & 48.8 & 41.6 & 20.3 & 8.7 & 1.1 & 447 & $150^{\mathrm{a}}$ \\
{$\left[\mathrm{MoO}_{2} \mathrm{~L}^{1}\right]_{2}$} & 68.8 & 22.8 & 15.7 & 21.8 & 2.1 & 687 & $377^{\mathrm{b}}$ \\
{$\left[\mathrm{MoO}_{2} \mathrm{~L}^{2}\right]_{2}$} & 53.4 & 35.8 & 19.1 & 8.1 & 1.0 & 535 & $187^{\mathrm{b}}$ \\
{$\left[\mathrm{MoO}_{2} \mathrm{~L}^{3}\right]_{2}$} & 61.0 & 22.7 & 13.9 & 21.2 & 1.8 & 612 & $165^{\mathrm{a}}$ \\
\hline
\end{tabular}

${ }^{\mathrm{a}} 1 \mathrm{~h},{ }^{\mathrm{b}} 0.5 \mathrm{~h}$

In the case of the reactions catalyzed by $\left[\mathrm{MoO}_{2}(\mathrm{SAP})\right]_{2}$ and $\left[\mathrm{MoO}_{2} \mathrm{~L}^{1}\right]_{2}$, the catalyst is totally dissolved, giving similar bright orange solutions. The $\left[\mathrm{MoO}_{2} \mathrm{~L}^{3}\right]_{2}$ catalyst dissolves slowly but is eventually fully dissolved in the reaction mixture. Qualitatively, the trend of the dissolution rate is $\left[\mathrm{MoO}_{2} \mathrm{~L}^{1}\right]_{2} \sim\left[\mathrm{MoO}_{2}(\mathrm{SAP})\right]_{2}>\left[\mathrm{MoO}_{2} \mathrm{~L}^{2}\right]_{2}>\left[\mathrm{MoO}_{2} \mathrm{~L}^{3}\right]_{2}$. Like for the epoxidation of cyclooctene, the highest activity is for the epoxidation of cyclohexene is exhibited by $\left[\mathrm{MoO}_{2} \mathrm{~L}^{1}\right]_{2}$ (see Figure 7). The slower conversion observed with the other catalysts, especially at the beginning of the reaction, might be due to the slow catalyst dissolution in the organic phase. The activity trend among the $\mathrm{OH}$ substituted compounds is the same as for the cyclooctene. The catalysts affording the highest cyclohexene conversion lead to a greater extent of ring opening. Indeed, $\left[\mathrm{MoO}_{2} \mathrm{~L}^{1}\right]_{2}$ and $\left[\mathrm{MoO}_{2} \mathrm{~L}^{3}\right]_{2}$ give less $\mathrm{CHO}$ than $\mathrm{CHD}$, while $\left[\mathrm{MoO}_{2} \mathrm{~L}^{2}\right]_{2}$ and $\left[\mathrm{MoO}_{2}(\mathrm{SAP})\right]_{2}$ give more $\mathrm{CHO}$ than $\mathrm{CHD}$. 


\subsection{DFT calculations}

A cycle for the epoxidation process catalyzed by the $\left[\mathrm{MoO}_{2} \mathrm{~L}\right]$ system with $\mathrm{L}=$ tridentate Schiff base has already been proposed on the basis of DFT calculations for the SAP system, using ethylene as model olefin [8a]. On the basis of this cycle, which is recalled in Scheme 4, the resting state is the TBHP adduct $\left[\mathrm{MoO}_{2} \mathrm{~L}(\mathrm{TBHP})\right]$ (I) and the rate-determining transition state (TS) corresponds to transfer of the TBHP $\mathrm{O}^{\alpha}$-atom to the outer-sphere olefin, for an energy span of $22.5 \mathrm{kcal} / \mathrm{mol}$ on the $\Delta \mathrm{H}$ scale. We have recently communicated the greater activity of the SATP system $\left(\mathrm{L}^{5}\right)$ and have shown by DFT calculations that the same proposed cycle gives a lower energy span of $22.3 \mathrm{kcal} / \mathrm{mol}$ [8b]. We have also recently reported a beneficial effect of an electron-withdrawing substituent on the aminophenol ring $\left(\mathrm{NO}_{2}\right)$ and a negative effect of an electron donating substituent on the salicyl ring $\left(\mathrm{NEt}_{2}\right)$ on the catalytic activity of modified SAP catalysts; the DFT calculations, based again on the same mechanism, provided variation of the energy spans in qualitative agreement with the experimental results $(21.0 \mathrm{kcal} / \mathrm{mol}$ for the former, $23.8 \mathrm{kcal} / \mathrm{mol}$ for the latter) [15]. We have therefore wished to verify whether this mechanism is also able to reconcile the observed activity trend of the $\left[\mathrm{MoO}_{2} \mathrm{~L}^{1-3}\right]$ systems.

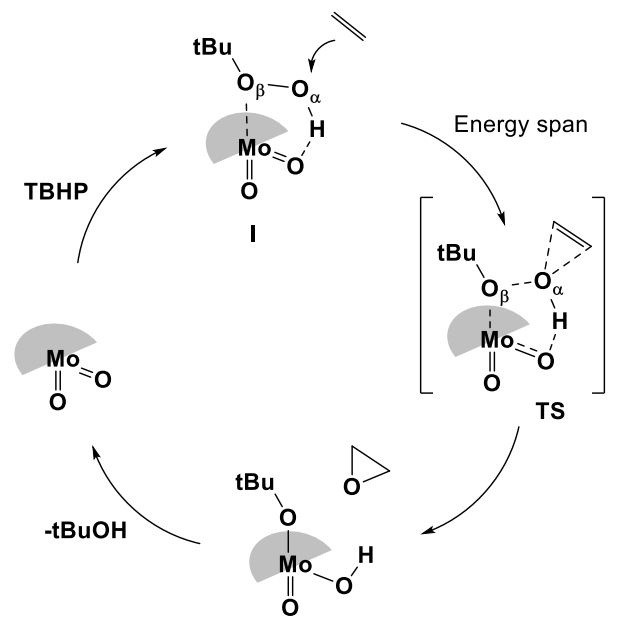

Scheme 4. Proposed cycle for the olefin epoxidation catalyzed by $\left[\mathrm{MoO}_{2} \mathrm{~L}\right][8]$.

All the key structures involved in the catalytic cycle have been recalculated for the $\mathrm{L}^{1}, \mathrm{~L}^{2}$ and $\mathrm{L}^{3}$ systems; optimized geometries and energies are reported in the SI (Tables S7 and S8). Relative to the 5-coordinate $\left[\mathrm{MoO}_{2} \mathrm{~L}\right]$, TBHP coordination gives very similar stabilization ranging from 8.3 to 8.5 $\mathrm{kcal} / \mathrm{mol}$ on the $\Delta \mathrm{H}$ scale for all systems (SAP, -8.4; $\mathrm{L}^{1},-8.5 ; \mathrm{L}^{2},-8.5 ; \mathrm{L}^{3},-8.3$ ). The relative TS enthalpy $(\mathrm{G})$ is also very similar for all systems (SAP, $14.1 ; \mathrm{L}^{1}, 13.9 ; \mathrm{L}^{2}, 14.4 ; \mathrm{L}^{3}, 14.3$ ). The result for the enthalpy span, $E S_{\mathrm{H}}=\Delta \mathrm{H}(\mathbf{T S})-\Delta \mathrm{H}(\mathbf{I})$, is roughly consistent with the experimentally observed activity differences when cyclooctene is the substrate: $\mathbf{E S}_{\mathbf{H}}\left(\mathbf{L}^{1}\right)(22.4)<\mathbf{E S}_{\mathbf{H}}(\mathbf{S A P})(22.5)<\mathbf{E S} \mathbf{S}_{\mathbf{H}}\left(\mathbf{L}^{\mathbf{3}}\right)$ $(22.6)<\mathbf{E S}\left(\mathbf{L}^{2}\right)_{\mathbf{H}}(22.9)$. 


\section{Conclusions}

The effect of $\mathrm{OH}$ substituents at different positions of the salicyl ring of the SAP ligand has been evaluated for the epoxidation of cyclooctene and cyclohexene by aqueous TBHP catalyzed by dimeric molybdenum complexes $\left[\mathrm{MoO}_{2} \mathrm{~L}\right]_{2}$ under organic solvent-free conditions. The position of the $\mathrm{OH}$ substituent and the nature of the substrate have a slight influence on the catalytic activity. DFT calculations on the catalytic cycle give a trend of energy spans in accordance with the experimental results. Further ligand tuning remains of interest for several purposes. The optimization of catalytic activity and selectivity are to be improved, as well suitable groups for grafting on solid supports and heterogeneization of the most stable and active complexes in order to allow efficient catalyst recovery.

\section{Experimental part}

\subsection{Materials and methods}

All preparations were carried out in air. Water was distilled before use. Organic solvents (ethanol, methanol, diethylether and acetrontrile) and organic compounds (TBHP (70\% in water, ACROS), cyclooctene (98\%, Aldrich), cyclooctene oxide (98\%, Aldrich), cyclohexene (purity, supplier), cyclohexene oxide (purity, supplier), trans-cyclohexanediol (purity, supplier), 2-cyclohexen-1-ol (purity, supplier), 2-aminophenol (99\%, Aldrich), 2,5-dihydroxybenzaldehyde (98\%, Aldrich), 2,3dihydroxybenzaldehyde (97\%, Aldrich), 2,4-dihydroxybenzaldehyde (98\%, Aldrich), salicylaldehyde (98\%, Aldrich) were used as received without any purification. The $\mathrm{H}_{2} \mathrm{SAP}$ and $\mathrm{H}_{2} \mathrm{~L}^{1-3}$ compounds were synthesized and characterized according to literature (see SI) [8a,17-19]]. [ $\mathrm{MoO}_{2}(\mathrm{acac})_{2}$ ] was synthesized as previously described [26] and used freshly prepared. Complex $\left[\mathrm{MoO}_{2}(\mathrm{SAP})\right]_{2}$ was prepared as described earlier [8a]. The thermogravimetric analyses were performed on a SETARAM TGA 92-16.18 thermal analyzer. The sample was placed into a nickel/platinum alloy crucible and heated at $0.83{ }^{\circ} \mathrm{C} \mathrm{s}^{-1}$ in a reconstituted air flow from $15^{\circ} \mathrm{C}$ to $700^{\circ} \mathrm{C}$. An empty crucible was used as a reference. Infrared spectra were recorded in $\mathrm{KBr}$ matrices at room temperature with a Mattson Genesis II FTIR spectrometer. ${ }^{1} \mathrm{H}$ spectra were recorded at $200.1 \mathrm{MHz}$ on a Bruker Avance DPX-200 spectrometer. Catalytic reactions were followed by gas chromatography on an Agilent 6890A chromatograph equipped with FID detector, a HP5-MS capillary column $(0.30 \mathrm{~m}$ x $0.25 \mathrm{~mm}$ x $0.25 \mathrm{~m})$ and automatic sampling, or on a Fisons GC 8000 chromatograph equipped with FID detector and with a SPB-5 capillary column $(30 \mathrm{~m} \times 0.32 \mathrm{~mm} \times 0.25 \mathrm{~m})$. The GC parameters were quantified with authentic samples of the reactants and products. The conversion of cis-cyclooctene, cyclohexene and the formation of cyclooctene oxide, cyclohexene oxide and cyclohexanediol were calculated from calibration curves $\left(r^{2}=0.999\right)$ relatively to an internal standard. 


\subsection{Synthesis of the Mo complexes}

$\left[\mathbf{M o O}_{2} \mathbf{L}^{1}(\mathbf{M e O H})\right]$ and $\left[\mathbf{M o O}_{2} \mathbf{L}^{1}\right]_{2}$. In a $100 \mathrm{~mL}$ Erlenmeyer flask, $\mathrm{H}_{2} \mathrm{~L}^{1}(0.35 \mathrm{~g}, 1.53 \mathrm{mmol})$ was dissolved in $20 \mathrm{~mL}$ of methanol and then $\left[\mathrm{MoO}_{2}(\mathrm{acac})_{2}\right](0.50 \mathrm{~g}, 1.53 \mathrm{mmol})$ was added. The mixture was refluxed under magnetic stirring for 4 hours. The resulting red solution was left to stand overnight, leading to the separation of orange needles characterized as $\left[\mathrm{MoO}_{2} \mathrm{~L}^{1}(\mathrm{MeOH})\right](80 \%)$. These needles were treated under reduced pressure at $80^{\circ} \mathrm{C}$ for 12 hours, leading to $\left[\mathrm{MoO}_{2} \mathrm{~L}^{1}\right]_{2}$ as brown solid. Addition of $\mathrm{MeOH}$ to this solid led a color change indicating the regeneration of $\left[\mathrm{MoO}_{2} \mathrm{~L}^{1}(\mathrm{MeOH})\right]$. [ $\left.\mathbf{M o O}_{2} \mathbf{L}^{\mathbf{1}}(\mathbf{M e O H})\right]:$ TGA: $\exp$ (theo) $\Delta \mathrm{m}_{1}$ over $20-120{ }^{\circ} \mathrm{C}=8.3(9.8), \Delta \mathrm{m}_{2}$ over 250-600 ${ }^{\circ} \mathrm{C}=62.8(63.4) \%$. IR (KBr): 908, $933(\mathrm{Mo}=\mathrm{O}) 1612(\mathrm{C}=\mathrm{N}) \mathrm{cm}^{-1}$. [MoO $\left.\mathbf{M}^{\mathbf{1}}\right]_{2}: \mathrm{TGA}:$ $\exp$ (theo) $\Delta \mathrm{m}$ over $200-600{ }^{\circ} \mathrm{C}=59.4(59.5) \%$. IR (KBr):919 (Mo=O) $780(\mathrm{Mo}-\mathrm{O}-\mathrm{Mo}), 1612(\mathrm{C}=\mathrm{N})$ $\mathrm{cm}^{-1}$. Anal. Calcd. for $\mathrm{C}_{13} \mathrm{H}_{9} \mathrm{MoNO}_{5}(\mathrm{Mr}=355.15): \mathrm{C}, 43.96 ; \mathrm{H}, 2.55 ; \mathrm{N}, 3.9 \%$. Found: $\mathrm{C}, 43.01 ; \mathrm{H}$, 1.97; N, $3.90 \%$. ${ }^{1} \mathrm{H}$ NMR (300 MHz, DMSO- $d_{6}, \delta(\mathrm{ppm})$ ): 6.82-6.96 (m, 3H, ArH), 7.05-7.08 (m, $1 \mathrm{H}$, Ar-H), 7.19-7.24 (m, 2H, Ar-H), 7.80-7.82 (m, 1 H, Ar- H), 9.21 (s, $1 \mathrm{H}, \mathrm{CH}=\mathrm{N}), 9.32$ (s, $1 \mathrm{H}, \mathrm{Ar}-\mathrm{OH})$. This ${ }^{1} \mathrm{H}$ NMR spectrum in DMSO- $d_{6}$ is the same as that for $\left[\mathrm{MoO}_{2} \mathrm{~L}^{1}(\mathrm{MeOH})\right]$, suggesting that for both compounds the stable species in solution is $\left[\mathrm{MoO}_{2} \mathrm{~L}^{2}(\mathrm{DMSO})\right] \cdot{ }^{13} \mathrm{C}$ NMR (300 MHz, DMSO- $d_{6}$, $\delta(\mathrm{ppm})): 160.3\left(\mathrm{C}_{\mathrm{q}}-\mathrm{O}\right), 157.3\left(\mathrm{C}_{\mathrm{H}}-\mathrm{N}\right), 150.3\left(\mathrm{C}_{\mathrm{q}}-\mathrm{O}\right), 147.0\left(\mathrm{C}_{\mathrm{q}}-\mathrm{O}\right), 135.9\left(\mathrm{C}_{\mathrm{q}}-\mathrm{N}\right), 130.5\left(\mathrm{C}_{\mathrm{H}}-\mathrm{Ar}\right), 125.7$ $\left(\mathrm{C}_{\mathrm{H}}-\mathrm{Ar}\right), 122.9\left(\mathrm{C}_{\mathrm{q}}\right), 121.5\left(\mathrm{C}_{\mathrm{H}}-\mathrm{Ar}\right), 121.4\left(\mathrm{C}_{\mathrm{H}}-\mathrm{Ar}\right), 120.7\left(\mathrm{C}_{\mathrm{H}}-\mathrm{Ar}\right), 117.7\left(\mathrm{C}_{\mathrm{H}}-\mathrm{Ar}\right), 116.8\left(\mathrm{C}_{\mathrm{H}}-\mathrm{Ar}\right)$.

$\left[\mathrm{MoO}_{2} \mathbf{L}^{2}(\mathbf{E t O H})\right]$ and $\left[\mathrm{MoO}_{2} \mathbf{L}^{2}\right]_{2}$. In a $100 \mathrm{~mL}$ Erlenmeyer flask, $0.70 \mathrm{~g}$ of $\mathrm{H}_{2} \mathrm{~L}^{2}$ (3.05 mmol) was dissolved in $25 \mathrm{~mL}$ of ethanol and $1.00 \mathrm{~g}$ of $\left[\mathrm{MoO}_{2}(\mathrm{acac})_{2}\right](3.06 \mathrm{mmol})$ was added. The mixture was refluxed under magnetic stirring over night. The resulting precipitate was separated by filtration giving orange needles of $\left[\mathrm{MoO}_{2} \mathrm{~L}^{2}(\mathrm{EtOH})\right]$. When dried under reduced pressure at $120^{\circ} \mathrm{C}$ for 12 hours, $\left[\mathrm{MoO}_{2} \mathrm{~L}^{2}\right]_{2}$ is obtained as a red-brown solid. Addition of EtOH to this solid led a color change indicating the regeneration of $\left[\mathrm{MoO}_{2} \mathrm{~L}^{2}(\mathrm{EtOH})\right]$. [ $\left.\mathbf{M o O}_{2} \mathbf{L}^{2}(\mathbf{E t O H})\right]$ : TGA: $\exp$ (theo) $\Delta \mathrm{m}_{1}$ over 20-200 ${ }^{\circ} \mathrm{C}=11.6(11.5) \%, \Delta \mathrm{m}_{2}$ over $200-600{ }^{\circ} \mathrm{C}=62.8(63.4) \%$. IR $(\mathrm{KBr}): 908,945(\mathrm{Mo}=\mathrm{O}), 1600(\mathrm{C}=\mathrm{N})$ $\mathrm{cm}^{-1}$. $\left[\mathrm{MoO}_{2} \mathbf{L}^{2}\right]_{2}$ : TGA: exp(theo) $\Delta \mathrm{m}$ over $200-600{ }^{\circ} \mathrm{C}=61.6$ (59.5) \%. IR (KBr): 821(Mo-O-Mo), $904(\mathrm{Mo}=\mathrm{O}), 1598(\mathrm{C}=\mathrm{N}) \mathrm{cm}^{-1}$. Anal. Calcd. for $\mathrm{C}_{13} \mathrm{H}_{9} \mathrm{MoNO}_{5}(\mathrm{Mr}=355.15): \mathrm{C}, 43.96 ; \mathrm{H}, 2.55 ; \mathrm{N}$, $3.9 \%$. Found: C, 43.93; H, 2.10; N, $3.92 \%$. ${ }^{1} \mathrm{H}$ NMR (300 MHz, DMSO- $d_{6}, \delta(\mathrm{ppm})$ ): $6.28(\mathrm{~s}, 1 \mathrm{H}, \mathrm{Ar}-$ H), 6.49-7.18 (m, 4H, Ar-H), 7.55-7.74 (m, 2 H, Ar-H), 9.03 (s, 1 H, CH=N), 10.65 (s, 1 H, Ar-OH). This ${ }^{1} \mathrm{H}$ NMR spectrum in DMSO- $d_{6}$ is the same for monomer and dimer, suggesting that for both compounds the stable species in solution is $\left[\mathrm{MoO}_{2} \mathrm{~L}^{2}(\mathrm{DMSO})\right] .{ }^{13} \mathrm{C}$ NMR (300 MHz, DMSO- $d_{6}$, $\delta(\mathrm{ppm})): 165.4\left(\mathrm{C}_{\mathrm{H}}-\mathrm{N}\right), 163.6\left(\mathrm{C}_{\mathrm{q}}-\mathrm{O}\right), 159.9\left(\mathrm{C}_{\mathrm{q}}-\mathrm{O}\right), 156.3\left(\mathrm{C}_{\mathrm{H}^{-}} \mathrm{Ar}\right), 137.4\left(\mathrm{C}_{\mathrm{H}^{-}}-\mathrm{Ar}\right), 136.7\left(\mathrm{C}_{\mathrm{q}}-\mathrm{N}\right)$, $129.4\left(\mathrm{C}_{\mathrm{H}}-\mathrm{Ar}\right), 120.8\left(\mathrm{C}_{\mathrm{H}}-\mathrm{Ar}\right), 117.4\left(\mathrm{C}_{\mathrm{H}}-\mathrm{Ar}\right), 116.1\left(\mathrm{C}_{\mathrm{H}}-\mathrm{Ar}\right), 115.2\left(\mathrm{C}_{\mathrm{q}}\right), 110.6\left(\mathrm{C}_{\mathrm{H}}-\mathrm{Ar}\right), 105.1\left(\mathrm{C}_{\mathrm{H}}-\mathrm{Ar}\right)$.

$\left[\mathrm{MoO}_{2} \mathbf{L}^{3}\right]_{2}$. In a $100 \mathrm{~mL}$ Erlenmeyer flask, $\mathrm{H}_{2} \mathrm{~L}^{4}(0.45 \mathrm{~g}, 1.96 \mathrm{mmol})$ was dissolved in $30 \mathrm{~mL}$ of methanol and then $\left[\mathrm{MoO}_{2}(\mathrm{acac})_{2}\right](0.64 \mathrm{~g}, 1.96 \mathrm{mmol})$ was added. The mixture was refluxed under magnetic stirring for 4 hours. The resulting brown precipitate was separated by filtration. The 
precipitate was dried $\left(80{ }^{\circ} \mathrm{C}\right)$ under reduced pressure for 24 hours. Yield $87 \%$. TGA: $\exp ($ theo $) \Delta \mathrm{m}$ over 300-530 ${ }^{\circ} \mathrm{C}=58.7(59.5) \%$. IR (KBr): $804(\mathrm{Mo}-\mathrm{O}-\mathrm{Mo}), 912(\mathrm{Mo}=\mathrm{O}), 1613(\mathrm{C}=\mathrm{N}) \mathrm{cm}^{-1}$. Anal. Calcd. for $\mathrm{C}_{13} \mathrm{H}_{9} \mathrm{MoNO}_{5}(\mathrm{Mr}=355.15)$ : C, 43.96; H, 2.55; N, $3.9 \%$. Found: $\mathrm{C}, 43.84 ; \mathrm{H}, 1.83 ; \mathrm{N}, 3.84$ \%. ${ }^{1} \mathrm{H}$ NMR (DMSO-d 6 , $\delta(\mathrm{ppm})$ ): 6.75-7.24 (m, 6H, Ar-H) 7.78-8.82 (m, $\left.1 \mathrm{H}, \mathrm{Ar}-H\right), 9.15$ (s, $1 \mathrm{H}$, $\mathrm{CH}=\mathrm{N}), 9.43$ (s, $1 \mathrm{H}, \mathrm{Ar}-\mathrm{OH}) .{ }^{13} \mathrm{C}$ NMR (300 MHz, DMSO- $\left.d_{6}, \delta(\mathrm{ppm})\right): 160.6\left(\mathrm{C}_{\mathrm{q}}-\mathrm{O}\right), 156.9\left(\mathrm{C}_{\mathrm{H}}-\mathrm{N}\right)$, $155.0\left(\mathrm{C}_{\mathrm{q}}-\mathrm{O}\right), 151.4\left(\mathrm{C}_{\mathrm{q}}-\mathrm{O}\right), 136.0\left(\mathrm{C}_{\mathrm{q}}-\mathrm{N}\right), 130.6\left(\mathrm{C}_{\mathrm{H}}-\mathrm{Ar}\right), 123.8\left(\mathrm{C}_{\mathrm{H}}-\mathrm{Ar}\right), 122.5(\mathrm{Cq}), 120.6\left(\mathrm{C}_{\mathrm{H}}-\mathrm{Ar}\right)$, $119.7\left(\mathrm{C}_{\mathrm{H}^{-}}-\mathrm{Ar}\right), 119.4\left(\mathrm{C}_{\mathrm{H}^{-}}-\mathrm{Ar}\right), 117.8\left(\mathrm{C}_{\mathrm{H}^{-}}-\mathrm{Ar}\right), 116.9\left(\mathrm{C}_{\mathrm{H}^{-}}-\mathrm{Ar}\right)$.

\subsection{X-ray structural analyses.}

Single crystals of each compound $\left[\mathrm{MoO}_{2} \mathrm{~L}^{1}(\mathrm{DMSO})\right], \quad\left[\mathrm{MoO}_{2} \mathrm{~L}^{2}\left(\mathrm{H}_{2} \mathrm{O}\right)\right](\mathrm{MeCN})$ and $\left[\mathrm{MoO}_{2} \mathrm{~L}^{3}(\mathrm{DMSO})\right] \cdot 2 \mathrm{DMSO}$ were mounted under inert perfluoropolyether at the tip of glass fiber and cooled in the cryostream of a Bruker APEX2 CCD diffractometer. The structures were solved by direct methods (SIR97 [27]) and refined by least-squares procedures on $F^{2}$ using SHELXL-2013 [28]. In both compounds, the DMSO molecule linked to the molybdenum is disordered over two positions related by a pseudo mirror plane. This disorder has been modelised using the tools available in SHELXL-2013. The two disordered fragments were included in two different parts. Then the occupancy factor for the two sites was refined using the free variable restraining the sum of the occupancy factors to be equal to 1 . The ratio of the occupancy is $8 / 2$. All $\mathrm{H}$ atoms attached to carbon were introduced in calculation in idealised positions and treated as riding models The drawing of the molecules was realised with the help of ORTEP32 [29]. Crystal data and refinement parameters are shown inTable 6.

Table 6. Crystal data and structure refinement parameters for all compounds.

\begin{tabular}{llll}
\hline Formula & {$\left[\mathrm{MoO}_{2} \mathrm{~L}^{1}(\mathrm{DMSO})\right]$} & {$\left[\mathrm{MoO}_{2} \mathrm{~L}^{2}\left(\mathrm{H}_{2} \mathrm{O}\right)\right] \cdot \mathrm{CH}_{3} \mathrm{CN}$} & {$\left[\mathrm{MoO}_{2} \mathrm{~L}^{3}(\mathrm{DMSO})\right] \cdot 2 \mathrm{DMSO}$} \\
\hline Empirical formula & $\mathrm{C}_{15} \mathrm{H}_{15} \mathrm{MoNO} \mathrm{S}_{6}$ & $\mathrm{C}_{15} \mathrm{H}_{14} \mathrm{MoN}_{2} \mathrm{O}_{6}$ & $\mathrm{C}_{19} \mathrm{H}_{27} \mathrm{MoNO}_{8} \mathrm{~S}_{3}$ \\
\hline Formula weight & 436.30 & 414.22 & 589.54 \\
Temperature, $\mathrm{K}$ & $173(2)$ & $180(2)$ & $180(2)$ \\
Wavelength, $\AA$ & 0.71073 & 0.71073 & 0.71073 \\
Crystal system & Monoclinic & Monoclinic & Monoclinic \\
Space group & $\mathrm{P} 21 / \mathrm{c}$ & $\mathrm{I} 2 / \mathrm{a}$ & $\mathrm{P} 21 / \mathrm{n}$ \\
$\mathrm{a}, \AA$ & $21.202(5)$ & $15.1752(4)$ \\
$\mathrm{b}, \AA$ & $7.4084(4)$ & $6.599(5)$ & $7.5571(2)$ \\
$\mathrm{c}, \AA$ & $20.8805(12)$ & $24.110(5)$ & $22.2331(6)$ \\
$\alpha,{ }^{\circ}$ & $10.8957(6)$ & 90.0 & 90.0 \\
$\mathrm{~B},{ }^{\circ}$ & 90.0 & $106.582(5)$ & $105.963(2)$ \\
$\gamma,{ }^{\circ}$ & $99.961(2)$ & 90.0 & 90.0 \\
Volume, & 90.0 & $3233(3)$ & $2451.39(11)$
\end{tabular}




\begin{tabular}{|c|c|c|c|}
\hline $\mathrm{Z}$ & 4 & 8 & 4 \\
\hline Density (calc), Mg/m3 & 1.746 & 1.702 & 1.597 \\
\hline Abs. coefficient, mm-1 & 0.947 & 0.845 & 0.834 \\
\hline $\mathrm{F}(000)$ & 884 & 1664 & 1208 \\
\hline Crystal size, mm3 & $0.500 \times 0.200 \times 0.040$ & $0.625 \times 0.075 \times 0.05$ & $0.37 \times 0.35 \times 0.20$ \\
\hline$\theta$ range $^{\circ}$ & 2.134 to 28.281 & 3.210 to 29.520 & 1.457 to 30.031 \\
\hline Reflections collected & 27592 & 15189 & 96079 \\
\hline Indpt reflections (Rint) & $4114(0.0360)$ & $10994(0.040)$ & $7181(0.0291)$ \\
\hline Completeness, $\%$ & 99.6 & 99.9 & 100.0 \\
\hline Absorption correction & Multi-scan & Multi-scan & Multi-scan \\
\hline Max. /min. transmission & 0.7461 and 0.6777 & 1.0 and 0.948 & $0.7474 / 0.6860$ \\
\hline Refinement method & $\mathrm{F}^{2}$ & $\mathrm{~F}^{2}$ & $\mathrm{~F}^{2}$ \\
\hline Data /restraints/parameters & 4114 / 6 / 234 & 10994 / 3 / 220 & $7181 / 8 / 322$ \\
\hline Goodness-of-fit on $\mathrm{F}^{2}$ & 1.164 & 1.042 & 1.224 \\
\hline $\mathrm{R}_{1}, \mathrm{wR} 2[\mathrm{I}>2 \sigma(\mathrm{I})]$ & $0.0360,0.0923$ & $0.0315,0.0819$ & $0.0305,0.0792$ \\
\hline $\mathrm{R}_{1}$, wR2 (all data) & $0.0464,0.1004$ & $0.0424,0.0840$ & $0.0343,0.0815$ \\
\hline Residual density, e. $\AA^{-3}$ & $1.068 /-1.019$ & $0.570 /-0.466$ & $0.989 /-0.915$ \\
\hline
\end{tabular}

\subsection{Catalytic Procedures.}

Routine experiments. In a typical experiment, cyclooctene or cyclohexene (1 equiv) and catalyst ( $\mathrm{x}$ equiv, see tables) were mixed together and then stirred in air in a round bottom flask. Acetophenone was added as internal standard. The temperature was regulated at $80^{\circ} \mathrm{C}$ (see Tables $4,5, \mathrm{~S} 4$ and S5) and then THBP (70\% in water, y equiv, see tables) was added, starting the reaction. Samples of the organic phase $(0.1 \mathrm{~mL})$ were periodically withdrawn. The reaction was quenched by addition of $\mathrm{MnO}_{2}$ $(2 \mathrm{mg})$, followed by addition of diethylether $(2.5 \mathrm{~mL})$ and removal of the manganese oxide and residual water by filtration through silica before GC analysis.

Water effect. The effect of water was tested for the catalytic runs with $\left[\mathrm{MoO}_{2}(\mathrm{SAP})\right]_{2}$ and $\left[\mathrm{MoO}_{2} \mathrm{~L}^{1}\right]_{2}$ using the same experimental conditions as for the routine experiments except for adding additional water (seeTable S6).

\subsection{Computational Details.}

All input geometries were adapted from the X-ray structures of $\left[\mathrm{MoO}_{2}(\mathrm{SAP})(\mathrm{EtOH})\right]$ [22] and optimized without any symmetry constraint using the Gaussian 03 program suite [30]. The calculations used the standard B3LYP three-parameter functional [31] in conjunction with the 6-31G** basis set [32] for the $\mathrm{C}, \mathrm{H}, \mathrm{N}$, and $\mathrm{O}$ atoms and the CEP-31G* basis set [33] for molybdenum. The transition states were optimized using a preliminary scan of a relevant internal coordinate, 
followed by full optimization of the TS guided by knowledge of such coordinate. All optimized geometries were confirmed to be stationary points and local minima (for stable molecules and reaction intermediates) or first order saddle points (for the TS's) by frequency analyses. For the TS's, analysis of the imaginary frequency confirmed the expected motion along the reaction coordinate. The calculated frequencies were also used to derive the thermochemical parameters at $298 \mathrm{~K}$ according to the standard ideal gas approximation.

\section{Acknowledgements}

We acknowledge the Centre National de la Recherche Scientifique (CNRS) and the Institut Universitaire de France (IUF) for financial support, the Université Paul Sabatier and its Institut Universitaire Technologique for the facilities, and the China Scholarship Council for the fellowship of W.W. (No.201208370239). This work was granted access to the HPC resources of CINES under the allocation 2010-086343 made by GENCI (Grand Equipement National de Calcul Intensif) and to the resources of the CICT (Centre Interuniversitaire de Calcul de Toulouse, project CALMIP). 


\section{References}

1 (a) I. M. Pastor, M. Yus, Curr. Org. Chem. 9 (2005) 1-29.

(b) P. L. Matlock, W. L. Brown, N. A. Clinton, Chem. Ind. 77 (1999) 159-193.

(c) Z. S. Petrovic, Polym. Rev. 48 (2008) 109-155.

2 (a) R. N. McDonald, R. N. Steppel, J. E. Dorsey, Org. Synth. 50 (1970) 15-18.

(b) D. Swern, Org. Peroxides, Vol. 2 (Ed.: D. Swern), Interscience, New York, NY (1971) 355533.

(c) B. Plesnicar, Oxidation in Organic Chemistry, Part C, (Ed.: W. C. Trahanosky) Academic Press, New York, San Francisco, London (1978) 211-294.

3 R.A. Sheldon, Green Chem. 9 (2007) 1273-1283.

4 B. H. Lipshutz, N. A. Isley, J. C. Fennewald, E. D. Slack, Angew. Chem. Int. Ed. Engl. 52 (2013) 10952-10958.

5 (a) K. Alfonsi J. Colberg P. J. Dunn, T. Fevig, S. Jennings, T. A. Johnson, H. P. Kleine, C. Knight, M. A. Nagy, D. A. Perry, M. Stefaniak, Green Chem., 10 (2008) 31-36

(b) C. Capello, U. Fischer, K. Hungerbühler, Green Chem., 9 (2007) 927-934

(c) D. J. C. Constable, C. Jimenez-Gonzalez, R. K. Henderson, Org. Proc. Res. Dev. 11 (2007) $133-137$

6 (a) J. Kollar (Halcon International), US 3350422, 1967.

(b) J. Kollar (Halcon International), US 3351635, 1967.

(c) J. Kollar (Halcon International), US 3507809, 1970.

(d) J. Kollar (Halcon International), US 3625981, 1971.

(e) M. N. Sheng, G. J. Zajaczek, GB 1.136.923, 1968.

(f) K. A. Jorgensen, Chem. Rev. 1989, 89, 431-485;

(g) B. S. Lane, K. Burgess, Chem. Rev. 2003, 103, 2457-2473

(h) F. E. Kühn, A. M. Santos, M. Abrantes, Chem. Rev. 2006, 106, 2455-2475.

$7 \quad$ (a) Z. Dawoodi, R. L. Kelly, Polyhedron 5 (1986) 271-275.

(b) D. D. Agarwal, S. Shrivastava, Polyhedron 7 (1988) 2569-2573.

(c) D. D. Agarwal, J. Mol. Catal., 44 (1988) 65 - 77.

(d) J. M. Sobczak, J. J. Ziolkowski, Appl. Catal. A-Chem. 248 (2003) 261-268.

(e) M. Bagherzadeh, S. G. Esfahani, Sci Iran, Trans. C: Chem, Chem Eng. 17 (2010) 131-138.

(f) J. Zhao, X. Zhou, A. M. Santos, E. Herdtweck, C. C. Romão, F. E. Kühn, Dalton Trans. (2003) 3736-3742.

(g) S. L. Pandhare, R. R. Jadhao, V. G. Puranik, P. V. Joshi, F. Capet, M. K. Dongare, S. B. Umbarkar, C. Michon, F. Agbossou-Niedercorn, J. Organomet. Chem. $772-773$ (2014) 271-279

8 (a) J. Morlot, N. Uyttebroeck, D. Agustin, R. Poli, ChemCatChem., 5 (2013) 601-611.

(b) W. Wang, T. Vanderbeeken, D. Agustin, R. Poli, Catal. Commun. 63 (2015) 26-30.

9 (a) J. Pisk, D. Agustin, J. C. Daran, V. Vrdoljak, R. Poli, Adv. Synth. Catal., 353 (2011) 29102914.

(b) J. Pisk, B. Prugovečki, D. Matković-Čalogović, R. Poli, D. Agustin,V. Vrdoljak, Polyhedron, 33 (2012) 441-449.

(c) J. Pisk, B. Prugovečki, D. Matković-Čalogović, T. Jednačak, P. Novak, D. Agustin, V. Vrdoljak, RSC Adv., 4 (2014) 39000-39010.

(d) V. Vrdoljak, J. Pisk, D. Agustin, P. Novak, J. Parlov Vuković, D. Matković-Čalogović. New J. Chem., 38 (2014) 6176

(a) C. Cordelle, D. Agustin, J. C. Daran and R. Poli, Inorg. Chim. Acta, 364 (2010) 144-149. 
(b) J. Pisk, J.-C. Daran, R. Poli, D. Agustin, J. Mol. Catal. A: Chem., 403 (2015), 52-63.

11 B. Guérin, D. Mesquita Fernandes, J.-C. Daran, D. Agustin, R. Poli, New. J. Chem. 37 (2013) 3466-3475.

12 M. Loubidi, D. Agustin, A. Benharref, R. Poli, C. R. Chim. 17 (2014) 549-556.

13 R. Landau, G. A. Sullivan, D. Brown, Chemtech 9 (1979) 602-607.

14 P. D. Bartlett, Record Chem. Progress, 11 (1950) 47-51.

15 W. Wang, T. Guerrero, S. R. Merecias, H. García-Ortega, R. Santillan, J.-C. Daran, N. Farfán, D. Agustin, R. Poli, Inorg. Chim. Acta, 431 (2015) 176-183.

16 L. E. Clougherty, J. A. Sousa, G. M. Wyman, J. Org. Chem. 22 (1957) 462.

17 R. J. Argaueri, C. E. White, Analytical Chemistry 36 (1964) 2141-2144

18 A. D. Mulazimoglu, I. E. Mulazimoglu, B. Mercimek, E-Journal Of Chemistry .6 (2009) 965974

19 N. E. Eltayeb, S. G. Teoh, Hoong-Kun Fun, S. Chantrapromma, Acta Cryst. E 66 (2010) o1536-o1537

20 (a) O. A. Rajan, A. Chakravorty, Inorg. Chem. 20 (1981) 660-664.

(b) T. Glowiak, L. Jerzykiewicz, J. M. Sobczak, J. J. Ziolkowski,. Inorg. Chim. Acta, 356 (2003) 387-392.

(c) M. Cindric, N. Strukan, V. Vrdoljak, T. Kajfez, B. Kamenar, Z. Anorg. Allg. Chem., 628 (2002) 2113-2117

(d) K. Uzarevic, G. Pavlovic, M. Cindric, Polyhedron 52 (2013) 294-300.

(e) M. R. Maurya, S. Dhaka, F. Avecilla, , Polyhedron 67 (2014) 145-159.

(f) V. Vrdoljak, B. Prugovecki, D. Matkovic-Calogovic, T. Hrenar, R. Dreos, P. Siega, Cryst. Growth Des. 13 (2013) 3773-3784.

(g) V. Vrdoljak, B. Prugovecki, D. Matkovic-Calogovic, J. Pisk,, CrystEngComm 13 (2011) 4382-4390.

(h) M. Cindric, N. Strukan, V.Vrdoljak, B. Kamenar, Z Anorg. Allg. Chem. 630 (2004) 585-590

21 J. M. Sobczak, T. Głowiak, J.J. Ziółkowski, Trans. . Met. Chem. 15 (1990) 208-211

22 D. Agustin, C. Bibal, B. Neveux, J.-C. Daran, R. Poli, Z. Anorg. Allg. Chem. 635 (2009) 2120 2125 .

23 (a) W. Bansse, J. Fliegner, S. Sawusch, U. Schilde, E. Uhlemann Z. Naturforsch., B:Chem.Sci. ,53 (1998) 689

(b) L.B. Jerzykiewicz, J.M.Sobczak, J.J.Ziolkowski J.Chem.Res. (2000) 423

(c) S. Alghool, C. Slebodnick Polyhedron,67 (2014) 11

(d) M. Minelli, F. Namuswe, D. Jeffrey, A.L. Morrow, I.A. Guzei, D. Swenson, E. Bothe, T. Weyhermuller Inorg.Chem. ,45 (2006) 5455

(e) R. Takjoo, A. Akbari, S.Y. Ebrahimipour, H.A. Rrudbari, G. Bruno CR Chimie , 17 (2014) 1144

24 (a) L. Gusina, I. Bulhac, D. Dragancea, Y. A. Simonov, S. Shova, Revue Roumaine de Chimie 56 (2011) 981-985.

(b) N. K. Ngan, K. M. Lo, Kong Mun; C. S. R. Wong, Acta Cryst., E 67 (2011) m857.

(c) S. Yan, X. N. Fang, Q. Y. Luo, H. M. Chen, M. Q. Zhou, Acta Cryst, E62 (2006) m1994m1996.

(d) C. P. Rao, A. Sreedhara, P. V. Rao, M. B. Verghese, K. Rissanen, E. Kolehmainen, N. K. Lokanath, M. A. Sridhar, J. S. Prasad, J. Chem. Soc., Dalton Trans. (1998) 2383-2394.

(e) C. Bustos, O. Burckhardt, R. Schrebler, D. Carrillo, A. M. Arif, A. H. Cowley, C. M. Nunn, Inorg. Chem. 29 (1990) 3996-4001.

25 (a) S. Van de Vyver, Y. Román-Leshkov, Catal. Sci. Technol., 3 (2013) 1465-1479

(b) N. Saravanan, M. Sankaralingam, M. Palaniandavar, RSC Adv., 4 (2014) 12000-12011

(c) P. Chandra ${ }^{a}$, D. S. Doke, S. B. Umbarkar, K. Vanka, A. V. Biradar, RSC Adv., 5 (2015) 21125-21131 
26 G. J. J. Chen, J. W. McDonald, W. E. Newton, Inorg. Chem. 15 (1976) 2612-2615.

27 A. Altomare, M. C. Burla, M. Camalli, G. L. Cascarano, C. Giacovazzo, A. Guagliardi, A. G.

G. Moliterni, G. Polidori, R. Spagna, J. Appl. Cryst. 32 (1999) 115-119.

28 G. M. Sheldrick,. Acta Cryst. A64 (2008) 112-122.

29 (a) L. J. Farrugia, J. Appl. Cryst. 30 (1997) 565.

(b) M. N. Burnett, C. K. Johnson, C. K. (1996). ORTEPIII. Report ORNL-6895. Oak Ridge National Laboratory, Tennessee, USA

30 Gaussian 03, Revision D.01, M. J. Frisch, G. W. Trucks, H. B. Schlegel, G. E. Scuseria, M. A. Robb, J. R. Cheeseman, J. Montgomery, J. A., T. Vreven, K. N. Kudin, J. C. Burant, J. M.

Millam, S. S. Iyengar, J. Tomasi, V. Barone, B. Mennucci, M. Cossi, G. Scalmani, N. Rega, G. A. Petersson, H. Nakatsuji, M. Hada, M. Ehara, K. Toyota, R. Fukuda, J. Hasegawa, M. Ishida, T. Nakajima, Y. Honda, O. Kitao, H. Nakai, M. Klene, X. Li, J. E. Knox, H. P. Hratchian, J. B. Cross, C. Adamo, J. Jaramillo, R. Gomperts, R. E. Stratmann, O. Yazyev, A. J. Austin, R.

Cammi, C. Pomelli, J. W. Ochterski, P. Y. Ayala, K. Morokuma, G. A. Voth, P. Salvador, J. J. Dannenberg, V. G. Zakrzewski, S. Dapprich, A. D. Daniels, M. C. Strain, O. Farkas, D. K.

Malick, A. D. Rabuck, K. Raghavachari, J. B. Foresman, J. V. Ortiz, Q. Cui, A. G. Baboul, S. Clifford, J. Cioslowski, B. B. Stefanov, G. Liu, A. Liashenko, P. Piskorz, I. Komaromi, R. L. Martin, D. J. Fox, T. Keith, M. A. Al-Laham, C. Y. Peng, A. Nanayakkara, M. Challacombe, P. M. W. Gill, B. Johnson, W. Chen, M. W. Wong, C. Gonzalez, J. A. Pople, Gaussian, Inc., Wallingford CT, 2004.

31 (a) A. D. Becke, J. Chem. Phys. 98 (1993) 5648-5652.

(b) C. T. Lee, W. T. Yang, R. G. Parr, Phys. Rev. B, 37 (1988) 785-789.

(c) B. Miehlich, A. Savin, H. Stoll, H. Preuss, Chem. Phys. Lett. 157 (1989) 200-206.

32 (a) R. Ditchfield, W. J. Hehre, J. A. Pople, J. Chem. Phys. 54 (1971) 724-728.

(b) W. Hehre, R. Ditchfie, J. Pople, J. Chem. Phys. 56 (1972) 2257-2261.

(c) P. C. Hariharan, J. A. Pople, Theor. Chim. Acta 28 (1973) 213-222.

(d) P. C. Hariharan, J. A. Pople, Mol. Phys. 27 (1974) 209-214.

33 (a) W. J. Stevens, H. Basch, M. Krauss, J. Chem. Phys. 81 (1984) 6026-6033.

(b) W. J. Stevens, M. Krauss, H. Basch, P. G. Jasien, Can. J. Chem. 70 (1992) 612-630.

(c) T. R. Cundari, W. J. Stevens, J. Chem. Phys. 98 (1993) 5555-5565. 